\title{
METODE EKLEKTIK DALAM PEMBELAJARAN BAHASA ARAB
}

\author{
Ahmad Munawwir ${ }^{1}$ \\ ${ }^{1}$ Dosen Pendidikan Bahasa Arab FTK UIN Alauddin Makassar \\ e-mail:ahmad.munawwir@uin-alauddin.ac.id
}

DOI: $10.24252 / \mathrm{saa} . v 8 \mathrm{i} 1.15030$

\begin{abstract}
Abstrak
Penelitian ini bertujuan untuk mengkaji metode Eklektik, bagaimana proses pembelajaran dengan metode tersebut, serta bagaimana kelebihan dan kekurangannya. Jenis penelitian ini ialah library research atau studi kepustakaan, sedangkan teknik pengumpulan data dilakukan dengan menekankan pada kajian teks serta aspek analisa, kemudian mengumpulkan beberapa teks yang berhubungan dengan materi yang dikaji dengan mencari literatur-literatur yang berkaitan, baik itu dari materi penelitian, baik dari buku, jurnal dan artikel lain yang berhubungan dengan materi. Dari hasil penelitian ini dapat dipahami bahwa metode ini lahir sebagai sebuah bentuk usaha penggabungan dari metode yang sudah lahir terdahulu, kemudian metode ini tidak dikembangkan berdasarkan teori linguistik dan psikologi tertentu melainkan berdasarkan asumsi. Metode ini memiliki tujuan yang ingin dicapai yaitu tujuan dari beberapa metode yang dipilih dan digabungkannya, sehingga keterampilan bahasa bisa teramu semua pada metode ini. Metode Eklektik ini di dalam bahasa Arab dinamakan Thariqah Intiqaiyyah, Thariqah Mukhtarah, Thariqah Mudzawijah dan Thariqah Taulifiyah
\end{abstract}

Kata Kunci : Metode Eklektik; Metode Pembelajaran.

\section{PENDAHULUAN}

Hal yang seringkali menjadi sorotan dalam pembelajaran bahasa Arab atau bahasa asing lainnya adalah metode apa yang digunakan dalam proses pembelajaran tersebut, karena salah satu faktor penentu sukses atau tidaknya suatu pembelajaran sering kali dinilai dari sisi pemilihan dan penggunaan metode, sebab metodelah yang menentukan isi dan cara mengajarkan materi tersebut. Tidak mengherankan kalau di bidang pengajaran bahasa sering terjadi perubahan-perubahan dari metode $\mathrm{A}$ ke metode $\mathrm{B}$, kemudian kembali lagi ke metode A. Hal ini dapat terjadi karena di bidang pengajaran bahasa terdapat berbagai macam metode pengajaran dan di antara metode pengajaran bahasa Arab yang ada, tidak ada satupun yang paling baik dipakai untuk bermacam-macam tujuan pengajaran bahasa Arab, sebab semua metode itu masing-masing mempunyai kelebihan dan kekurangan. Tetapi bila guru dapat memilih dan menggunakannya dengan tepat yaitu sesuai dengan tujuan, materi, kemampuan siswa, kemampuan guru maupun keadaan waktu serta peralatan atau media pengajaran yang memadai, maka dapatlah tercapai apa yang diharapkan dalam proses belajar mengajar.

Salah satu metode pengajaran yang dapat digunakan dalam pengajaran bahasa Arab adalah Metode Pembelajaran Eklektik (al-Thariqah al-Intiqaiyyah) yaitu suatu metode pembelajaran yang lebih banyak menekankan pada kemahiran mendengar (istima'), berbicara (hiwar), menulis (kitabah), membaca (qiraah), dan memahami pengertian-pengertian tertentu. 
Pemakalah dalam makalah ini akan membahas tentang pengertian, tujuan dan proses pembelajaran, serta kelebihan dan kelemahan Thariqiyah intiqaiyyah ini.

Agar pembahasan lebih sistematis dan tersusun, maka penulis merumuskan beberapa sub masalah sebagai berikut:

1. Apa pengertian metode Eklektik?

2. Bagaimana proses pembelajaran metode Eklektik?

3. Bagaimana kelebihan dan kekurangan metode Eklektik?

\section{METODE}

Jenis penelitian ini ialah library research atau studi kepustakaan, sedangkan teknik pengumpulan data dilakukan dengan menekankan pada kajian teks serta aspek analisa, kemudian mengumpulkan beberapa teks yang berhubungan dengan materi yang dikaji dengan mencari literatur-literatur yang berkaitan, baik itu dari materi penelitian, baik dari buku, jurnal dan artikel lain yang berhubungan dengan materi. Adapun buku-buku yang menjadi rujukan seperti buku Acep Hermawan yang berjudul Metodologi Pembelajaran Bahasa Arab dan buku Hanafi Abdul Halim yang berjudul Thuruq Ta'lim Allughah Al 'Arabiyyah.

Penelitian yang dilaksanakan ini dengan mengorganisasikan data menjadi kategori yang tersusun secara sistematis, kemudian menjelaskannya kepada satuan-satuan, melakukan sintesis, menyusun kedalam pola, merumuskan serta memilah konsep yang dianggap paling penting dan terakhir membuat keterkaitan atau benang merah dengan tujuan bisa dipahami oleh pembaca.

Data-data yang dikumpulkan dari berbagai referensi dan referensi terbagi menjadi dua yaitu referensi utama dan referensi penunjang.

Metode pengolahan yang digunakan dalam penelitian sederhana ini adalah mengumpulkan berbagai buku dan jurnal yang berkaitan dengan materi, kemudian dianalisa hingga dapat ditarik beberapa kesimpulan.

\section{HASIL DAN PEMBAHASAN}

\section{A. Pengertian Metode Eklektik}

Metode Eklektik ini lahir berawal dari ketidakpuasan terhadap metode lain atau metode sebelumnya, tapi pada waktu yang sama metode itu terjebak dalam kelemahan yang dahulu menjadi penyebab lahirnya metode yang dikritiknya. Metode-metode datang silih berganti dengan kekuatan dan kelemahan yang silih berganti pula. Pada sisi lain pengajaran bahasa asing pasti menghadapi kondisi objektif yang berbeda-beda antara satu negeri dengan negeri yang lain, antara satu lembaga dengan lembaga yang lain, antara satu kurun waktu dengan kurun waktu yang lain, kondisi objektif itu meliputi tujuan pengajaran, keadaan guru, keadaan siswa, keadaan sarana prasarana dan lain sebagainya.

Berdasarkan kenyataan diatas, muncullah metode Eklektik, yang mengandung arti pemilihan dan penggabungan. Munculnya metode Eklektik ini merupakan kreativitas para pengajar bahasa asing untuk untuk mengefektifkan proses belajar mengajar bahasa asing. Metode ini juga memberi kebebasan kepada mereka untuk menciptakan variasi metode. ${ }^{1}$

\footnotetext{
${ }^{1}$ Acep Hermawan, Metodologi Pembelajaran Bahasa Arab, (Bandung, Remaja Rosdakarya, 2011), h.196.
} 
Dalam bahasa arab, metode ini memiliki penamaan yang bervariasi, diantaranya alThariqah al-Mukhtarah, al-Thariqah al-Taufiqiyyah, al-Thariqah al- Izdiwajiyyah, dan alThariqah al-Taulifiyyah. ${ }^{2}$

Metode ini dinamakan al-Thariqah al Khiyariyah karena unsur-unsurnya adalah gabungan dari unsur-unsur beberapa metode, seperti Thariqah Mubasyarah dan Thariqah al-Qawaid wa alTarjamah. $^{3}$

Dari pengertian di atas, dapat disimpulkan bahwa Thariqah Intiqaiyyah (metode Eklektik) adalah suatu metode pembelajaran yang lebih banyak menekankan pada kemahiran istima'(mendengar), kalam (berbicara), kitabah (menulis), qiraah (membaca), dan memahami pengertian-pengertian tertentu.

Dalam buku Zainul Arifin dijelaskan bahwa ada beberapa pandangan terhadap munculnya metode ini, yaitu:

1. Metode ini tidak sesuai bagi orang yang ingin memahami ilmu - ilmu bahasa secara mendalam. Bahasa yang digunakan pada metode lebih terkhusus, tidak terangkum, tidak tersusun.

2. Bahasa adalah budaya, untuk itu pembelajaran bahasa mesti berkaitan dengan kebudayaan.

3. Menggunakan bahasa tujuan terbatas seperti media pembelajaran

4. Terdiri dari satu susunan disetiap pembelajaran baik dari segi gramatika, kosa kata, dan lain-lain.

5. Metode ini mengajarkan empat maharah dalam satu jam.

6. Mengajarkan gramtika dengan bahasa tujuan.

7. Mengetahui bahasa tujuan dengan hiwar yang panjang serta berlawanan dalam pertanyaan dan jawaban. ${ }^{4}$

Adapun ciri - ciri metode ini adalah:

1. Pengajaran bahasa harus bermakna dan nyata.

2. Penerjemahan adalah kemampuan bahasa khusus dan tidak tepat untuk pelajar pemula.

3. Pengajaran bahasa harus diterapkan dengan menggunakan bahasa target.

4. Dalam metode ini tidak menekankan pada hafalan, mimik dan mempraktekkan struktur gramatika bahasa.

5. Bahwa membaca keras itu sebenarnya bukan model atau inti dari pembelajaran qiro'ah (membaca), akan tetapi hanya sebagai pengenalan huruf dan menyambungkan ant ar huruf dan kata atau kalimat. ${ }^{5}$

\section{B. Proses Pembelajaran Metode Eklektik}

Dalam bukunya Acep Hermawan mengemukakan langkah pembelajaran dengan metode Eklektik ini sebagai berikut:

1. Pendahuluan, sebagaimana metode-metode lain.

2. Memberikan materi berupa dialog-dialog pendek yang rilek, dengan tema kegiat an seharihari secara berulang-ulang. Materi ini mula-mula disajikan secara lisan dengan gerakangerakan, isyarat-isyarat, dramatisasi-dramatisasi atau gambar-gambar.

\footnotetext{
${ }^{2}$ Radliyah Zaenuddin, dkk, Metodologi \& Strategi Alternatif Pembelajaran Bahasa Arab, (Yogyakarta: Pustaka Rihlah Group, 2005) h.43.

${ }^{3}$ Bisri Mustofa dan M Abdul Hamid, Metode dan Strategi Pembelajaran Bahasa Arab, (Malang: UIN-Maliki Press, 2012), h. 62.

${ }^{4}$ Zainul Arifin, Allughah Tharaiq Ta'liimuha wa Ta'allimuha, (Padang : Padang Press, 2008), h. 207-208.

${ }^{5}$ Henry Guntur Taringan. Strategi Pengajaran dan Pembelajaran Bahasa. (Bandung: Angkasa, 1991). H 115.
} 
3. Para pelajar diarahkan untuk disiplin menyimak dialog-dialog tersebut, lalu menirukan diaog-dialog yang disajikan sampai lancar.

4. Para pelajar dibimbing menerapkan dialog-dialog itu dengan teman-teman secara bergiliran.

5. Setelah lancar menerapkan dialog-dialog yang telah dipelajari, maka diberi teks bacaan yang temanya berkait an dengan dialog-dialog tadi. Selanjutnya guru memberi contoh cara membaca yang baik dan benar, diikuti oleh para pelajar secara berulang-ulang.

6. Jika terdapat kosa kata yang sulit, guru memakainya, mula-mula dengan isyarat, atau gerakan, atau gambar, atau lainya. Jika tidak mungkin dengan inii semua, guru menerjemahkan kedalam bahas populer.

7. Guru mengenalkan beberapa struktur yang penting dalam teks bacaan, lalu membahas secukupnya.

8. Guru menyuruh para pelajar menelaah bacaan. Lalu mendiskusikan isinya.

9. Sebagai penutup, jika diperlukan, evaluasi akhir berupa pertanyaan-pertanyaan tent ang isi bacaan yang telah dibahas. ${ }^{6}$

Pelaksanaan bisa saja individual atau kelompok, sesuai dengan situasi dan kondisi. Jika memungkinkan karena waktu maka misalnya, guru dapat menyajikannya berupa tugas yang harus dikerjakan di rumah masing-masing

Langkah-langkah teks percakapan di dalam proses pembelajaran dengan memperdengarkannya, lalu membaca nyaring secara bersama. Guru menyuruh murid-murid untuk membaca teks percakapan dengan membaca nyaring secara bersama, lalu guru memberikan mufradat yang baru berkisar sekitar hiwar dan menuliskannya dipapan tulis baik sinonim maupun antonim serta maknanya, bagi setiap pembelajaran terdapat 5 atau 7 mufradat atau lebih, murid-murid wajib menghafal kosa kata di kelas maupun di rumah.

Setelah membca teks dan menuliskan kosa kata guru memerintahkan muridnya untuk berlatih (tadribat) sekitar teks untuk memahami materi pembelajaran yang terdiri dari tadribat syafahi, contoh: menjawab pertanyaan, mengulangi kalimat atau jumlah, mencobakan percakapan dan lain-lain. Dan tadribat kitabah menuliskan huruf, serta melakukan imla' dan lainya, setelah tadribat guru menjelaskan susunan gramatika yang terkandung dalam materi pembelajaran dengan menggunakan metode Istinbaiyyah.

Di akhir waktu pembelajaran guru memberikan latihan di luar teks yaitu menuntut memperkaya pembelajaran agar murid - murid bisa memahami materi yang diajarkan serta sanggup untuk digunakan baik Syafahi maupun Kitabiyyah, boleh jadi latihan ini merupakan PR, yang materinya selalu menggunakan metode eklektik yang juga berkaitan dengan materi yang terdahulu dari segi mufradat, tema maupun gramatika.

\section{Kelebihan dan Kelemahan Metode Eklektik}

Meski dengan metode Eklektik seorang guru mampu menggunakan berbagai metode dalam proses pengajaran sehingga kelemahan-kelemahan yang ada pada sebuah metode tertentu dapat diminimalisir, tetapi tetap tidak dapat dipungkiri bahwa setiap metode selalu memiliki kelebihan dan kelemahan masing-masing.

Di antara kelebihan metode ini adalah sebagai berikut:

1. Guru dapat membuat pengajaran lebih bervariasi dan lebih menarik

2. Masalah perbedaan individu, materi lingkungan belajar yang kurang menarik dapat dipecahkan

${ }^{6}$ Acep Hermawan, Metodologi Pembelajaran Bahasa Arab, (Bandung, Remaja Rosdakarya,2011), h. 198-199. 
3. Guru dapat lebih percaya diri dan meyakinkan dalam mengajarkan keterampilan berbahasa

4. Dapat digalakkan keaktifan siswa belajar dengan sistem CBSA

5. Guru dapat menyampaikan materi pelajaran secara lebih cepat.

6. Guru dapat menghidupkan suasana belajar mengajar di kelas.

7. Siswa akan bersemangat dalam belajar / tidak cepat jemu.

8. Dapat lebih membuat siswa berkonsentrasi pelajaran. ${ }^{7}$

Sedangkan di antara kelemahan-kelemahan metode ini yaitu:

1. Metode ini membutuhkan guru yang memiliki kredibilitas yang tinggi, tidak hanya dalam bidang yang ia akan ajarkan tetapi juga tentang berbagai metode.

2. Guru dituntut untuk menguasai metode berbagai metode sehingga bisa menggabungkannya dengan metode yang lain.

3. Guru harus benar-benar mengetahui dan memahami esensi setiap metode sebelum menggabungnya.

4. Penggabungan akan menjadi fatal apabila guru asal-asalan menggabungkan beberapa metode tanpa memperhatikan tiap-tiap kansepnya.

5. Metode ini tidak maampu mencapai hasil pembelajaran yang maksimal apabila metode ini tidak diberikan perhatian yang maksimal pula. ${ }^{8}$

\section{KESIMPULAN}

Metode campuran ini di dalam bahasa Arab metode ini dinamakan Thariqah Intiqaiyyah, Thariqah Mukhtarah, Thariqah Mudzawijah dan Thariqah Taulifiyah. Metode ini lahir sebagai sebuah bentuk usaha penggabungan dari metode yang sudah lahir terdahulu, kemudian metode ini tidak dikembangkan berdasarkan teori linguistik dan psikologi tertentu melainkan berdasarkan asumsi. Metode ini memiliki tujuan yang ingin dicapai yaitu tujuan dari beberapa metode yang dipilih dan digabungkannya, sehingga keterampilan bahasa bisa teramu semua pada metode ini.

Adapun kelebihan dan kekurangan dari metode ini sebenarnya kita dapat mengetahui kekurangan dan kelebihan dari suatu metode itu setelah di implementasikan, karena tidak ada tolok ukur yang mutlak untuk di katakan metode ini mempunyai sisi kelebihan dan kekurangan. Namun kami menemukan dari sumber lain bisa dikatakan metode ini menjadi seadanya jika guru itu menggunakan dengan sistem "semau guru" dan bisa dikatakan metode ini menjadi ideal jika guru tersebut menguasai semua metode dan dapat mengambil secara tepat segi-segi kekuatan dari setiap metode dan menyesuaikan dengan kebutuhan program pengajaran yang ditanganinya.

\section{DAFTAR PUSTAKA}

Arifin, Zainul, Allughah Tharaiq Ta'liimuha wa Ta'allimuha, Padang : Padang Press: 2008.

Dahlan, Juwairiyah, Metode Belajar Mengajar Bahasa Arab, Surabaya: Usaha NasionalSurabaya: 1992.

\footnotetext{
${ }^{7}$ Drs. Zulkifli, Metodologi pengajaran bahasa Arab, (Riau: Zanafa publishing, 2011), h 42.

${ }^{8}$ Drs. Zulkifli, Metodologi pengajaran bahasa Arab, (Riau: Zanafa publishing, 2011), h 42.
} 
Hermawan, Acep., Metodologi Pembelajaran Bahasa Arab, Bandung, Remaja Rosdakarya: 2011.

Mustofa, Bisri., dan M Abdul Hamid, Metode dan Strategi Pembelajaran Bahasa Arab, Malang: UIN-Maliki Press: 2012.

Radliyah Zaenuddin, dkk, Metodologi \& Strategi Alternatif Pembelajaran Bahasa Arab, Yogyakarta:Pustaka Rihlah Group: 2005.

Taringan, Henry Guntur. Strategi Pengajaran dan Pembelajaran Bahasa. Bandung: Angkasa: 1991.

Zulkifli, Drs., Metodologi pengajaran bahasa Arab, Riau: Zanafa publishing: 2011. 